\title{
An Attempt to Establish the Scale and Orientation of the "Map of Lobzow with Its Environs"
}

\begin{abstract}
This work concerns the assessment of the cartometricity of the 19th century plan of the village of Lobzow near Krakow in Poland, known as "Mapa Łobzowa z przyległościami". The plan has not been researched in this respect so far. The aim of this study was to establish its scale and orientation in relation to directions of the world. A high resolution raster of the plan provided by the Historical Museum of the City of Krakow was used for the study. At first, an attempt was made to clarify the date of the plan's origin. An analysis of information contained in archival documents shows that the plan of Lobzow was most probably created between 1824 and 1852, which corresponds with the period when the large-scale cadastral map was developed in Galicia. Therefore, selected sections of this map, from the area covered by the plan, were used for research. The scale value of the Lobzow plan was calculated using the lengths of sections between selected points on the plan and map. The calculated plan scale is close to the scale of the detailed map section detailed sheet of the cadastral map. It was established that the plan of Lobzow has the orientation relative to magnetic north as was common in the first half of the 19th century. The mutual dependencies between the orientation of the plan and the cadastral map in relation to the direction of true geographical north were illustrated. The final result of the work was to show the changes in the topography of Lobzow that have taken place over nearly 200 years.
\end{abstract}

Keywords: historical cartography, cadastral map, Poland

Received: 7 July 2021; accepted: 11 October 2021

(C) 2022 Author. This is an open access publication, which can be used, distributed and reproduced in any medium according to the Creative Commons CC-BY 4.0 License.

AGH University of Science and Technology, Faculty of Mining, Surveying and Environmental Engineering, Krakow, Poland, email: pbanasik@agh.edu.pl, (D) https://orcid.org/0000-0002-3604-4019

2 The article was prepared under the research subvention of AGH University of Science and Technology No. 16.16.150.545. 


\section{Introduction}

"Mapa Łobzowa z przyległościami" ("Map of Lobzow with Its Environs") is the name of a 19th-century plan that presents the topography and land development part of the village of Lobzow (Łobzów) near Krakow (currently in the 5th district of Krakow-Krowodrza, in Poland). This plan was found in the 1980s in the collections of the Historical Museum of the City of Krakow [1], and made available in a digital form [2] $]^{3}$. The exact date of its creation is unknown. The name of its author has also not been determined. So far, this little-known plan of Lobzow has not been researched in terms of its cartographic properties. Research on such archival documents is the basis for further research in the field of identification and geographical location of objects, spatial arrangement of phenomena, determining their ranges and courses, e.g. examining borders, communication routes, changes in settlement, etc. [3]. Establishing the accuracy of an old map or plan is of paramount importance in studying the above-mentioned phenomena quantitatively. Therefore, in the first place, attempts are made to determine the georeference of such maps, or at least their scale and orientation. Research in this area has been frequently undertaken, both in terms of methodology and practice. Examples include the works [4-13]. They attest to the great and unflagging interest in archival cartographic documents.

Due to the probable period of the creation of the plan of Lobzow (mid-19th century), it should be compared with two other cartographic documents: the Kołłątaj's Plan from 1785 or the cadastral map from the mid-19th century. The above-mentioned cartographic documents have already been adequately researched $[6,14,15]$. They are the only large-scale documents from this period that contain the topography of the vicinity of Krakow, including Lobzow. The visual assessment of the topography presented on the plan of Lobzow resembles more the state of land development shown on the cadastral map. Moreover, the cadastral map, unlike the Kołłątaj's Plan, should be considered an accurate and more reliable cartographic document. In connection with the above, it was decided that the study of the scale and orientation of the Lobzow plan would be carried out in relation to the cadastral map. The current topography of Lobzow, significantly changed compared to the one from 200 years ago, makes it impossible to conduct direct research, i.e. with reference to the current topography of this area.

\section{Description of the Plan of Lobzow}

The "Map of Lobzow with Its Environs" is also known as "K. Gołuchowski's Plan". This name comes from the added initials of the name and surname under the lower frame of the plan (Fig. 1). The plan of Lobzow was drawn in ink on paper sized

\footnotetext{
3 In the catalog, the map was called "Plan części Łobzowa z pałacem i ogrodem".
} 
$45.2 \mathrm{~cm} \times 55.8 \mathrm{~cm}$ [2]. Lobzow shown on the plan occupies an area of over $1 \mathrm{~km}^{2}$. What stands out in the plan is the centrally located garden area at the Lobzow Palace and the Młynówka Królewska River, encircling it from the south and east (Fig. 1).

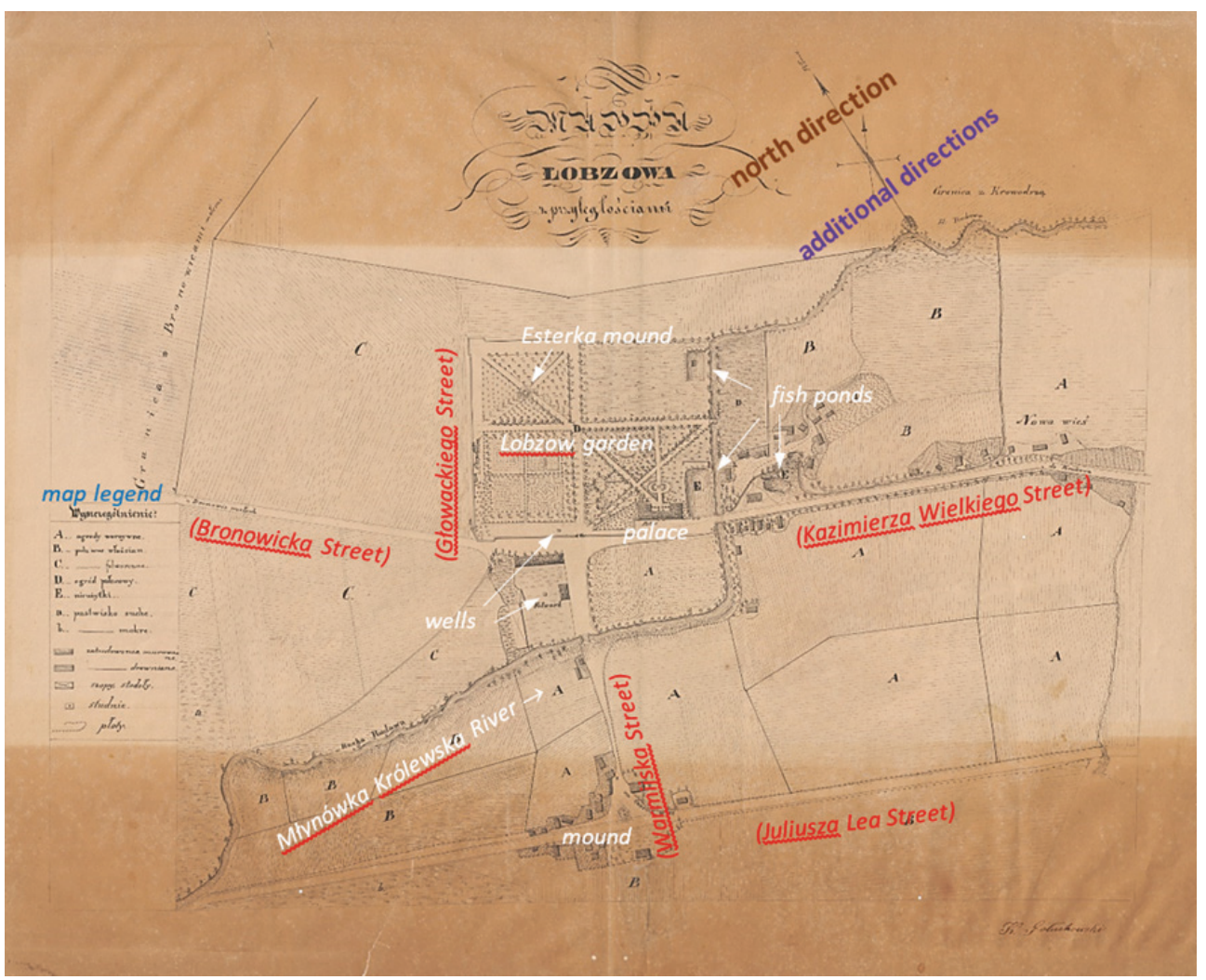

Fig. 1. The plan of Lobzow with topographic objects and the approximate course of the present streets

Source: own elaboration based on [2]

Three main roads are also visible. The western road can be identified as a fragment of the present Bronowicka Street (Figs. 1, 5 - Chap. 6, p. 47). Its extension roughly to the east coincides with a fragment of the present Kazimierza Wielkiego Street. The longest road running on the east-west axis is on the southern edge of the plan. It should be identified as the current Juliusza Lea Street. The only road running longitudinally is the present Warmijska Street (Figs. 1, 5).

On the southern edge of this road, a small mound with a cross was marked using hachure marks. This mound has been preserved to this day, at the intersection of Warmijska and Lea streets. Along the roads on the plan, the locations of the few buildings and bodies of water (ponds) were marked. Apart from the topographic 
content, the borders of arable land were marked on the plan of Lobzow, but without detailed borders between individual land parcels. The type of arable land is explained in the legend to the left of the plan. In the legend, you can also find the symbols of buildings divided into permanent and non-permanent, symbols of fences and even wells. The wooded areas were marked on the plan using the sign method. In the part of the plan that shows the palace garden, alleys and flowerbeds were marked, with the centrally located Esterka's mound (Fig. 1). The mound has not survived to this day, but its location has been recreated using old maps of the vicinity of Krakow [16].

Few elements of Lobzow's topography shown on the map have been preserved to the present day. To this day, the above-mentioned lines of roads (fragments of the present streets), as well as the mound with a cross at the end of Warmijska Street (Fig. 1) have survived. It is highly probable that the western fence of the garden (along the present Głowackiego Street) can be included among the preserved elements of the topography. In terms of the surviving buildings from that period, only the southern wing of the palace (expanded in the 19th century) can be mentioned. This shape of the palace and the condition of the garden make it possible to estimate the date when the plan of Lobzow was drawn up. At the end of the 17th century, the Lobzow Palace was a building closed around an internal courtyard. It obtained such a closed form in the second half of the 16th century [17]. War damage from the beginning of the 18th century and the lack of renovations meant that at the beginning of the 19th century, only the remains of the southern wing were left of the palace. The open form of the palace can be seen on Kołłątaj's Plan from 1795 [6]. In 1824, the southern wing of the palace was renovated, and the ruins of the remaining wings were removed [18]. The alleys of the palace garden were also put in order and reconstructed. Comparing the condition of the garden from Kołłąaj's Plan with its condition on the plan of Lobzow, the latter shows more details of the composition of the garden (alleys, flowerbeds, ponds, etc.). It is also known that this area of Lobzow was purchased in 1852 by the Austrian authorities to organise a military school [18]. The palace was then extended to its present form (the western part of the palace was enlarged). This old and new form of the building can be seen on the cadastral map from 1848 (Fig. 3a-Chap. 5, p. 43). The outline of the new building is marked there in red against the background of its original shape (black) (Fig. 3a). The course of events described above shows that the condition of the palace and garden presented on the plan of Lobzow dates back to the period between 1824 and 1852 .

The purpose of the plan of Lobzow has not yet been established. Perhaps it was an inventory of the state of the palace and garden after the modernisation works and the state of land development in the immediate vicinity. Thus, it could be a supporting document, e.g. in a planned sale or lease transaction of this area.

Important information that indicates the cartometric properties of a map or plan is the information concerning the manner in which they were prepared. However, no such information was provided on the plan of Lobzow. It lacks a frame that is 
typical for a map, as well as markings of the cartographic control network. The value of the plan scale was also not provided. The plan does not show geodetic control points or directions to landmarks, which was typical for the method of map preparation employed at that time - plane tabling. The only information that determines the orientation of the plan is the north arrow (Fig. 1). It is complemented by a line of an additional direction without a description, with perpendicular directions. This additional line deviates to the east of the marked north direction by nearly $25^{\circ}$. This line is almost perpendicular to the main and longest road on the southern edge of the plan (the deviation from the right angle is only $47^{\prime}$ ).

\section{Description of the Cadastral Map}

Cadastral maps for the area of Western Galicia were created at the end of the first half of the 19th century, i.e. at the time when the plan of Lobzow was most likely drawn. Their mathematical basis was the rectangular coordinate system $X, Y$, known as the Lviv cadastral system. The name "Lviv" refers to the starting point of the system $(X=0, Y=0)$, located on the Castle Hill in Lviv. The cadastral systems in Austria were developed as a result of triangulation measurements carried out in the years 1817-1830 and 1841-1851 [14]. The adopted $X$ and $Y$ axes of the Lviv system had a south-west orientation. The $X$ axis of the system divided the area of Galicia into two zones: the western (marked WC) and the eastern (marked OC). The cadastral map sheets in this system were created with grid reference. The area of a given zone was first divided into large triangulation sheets, and then into smaller, so-called detailed map sections at a scale of 1:2880. Topographic content and boundaries of properties are only found in detailed map sections. These map sections are also referred to as the "cadastral map in the Austrian partition". The above-mentioned scale of the map resulted from the established size of map sections, their adopted division and the unit of length (Viennese inch and fathom), used in Austria until 1876. The cadastral map sheets have a cartographic control network in the form of a rectangular frame with lines marked 1 inch apart (Fig. 2 - Chap. 4, p. 42). Neither the corners of the frame nor inch marks were described with coordinates. Due to the division of the cadastral communes, a given precinct with a specific name usually consisted of several fragments of map sections. A complete frame was not placed on such fragments of map sections. This is the case of the "Lobzow" precinct, which is covered by four detailed map sections (Fig. 2). On each of them, there is only one part of the frame along the $X$ axis, common to all map sections.

The cadastral coordinates of any point on a cadastral map can only be determined in relation to the coordinates of the corners of the given map section or the coordinates of the inch marks of the frame. For a given map section, these values should be calculated using its identification number, appropriate dependencies related to the size of the map section and the conversion of fathoms to meters. Using 
the dependencies given in [15], the coordinates of the lower left section of the map with the identification number "WC XXXIX 12dg" were calculated in the cadastral system: $X=-33378,11 \mathrm{~m}$ and $Y=295851,50 \mathrm{~m}$ (Fig. 2).

\section{Comparison of the Plan of Lobzow and the Cadastral Map}

Figure 2 shows the sections of the cadastral map for the Lobzow precinct. This precinct is included on the fragments of 4 detailed map sections (map section frames are marked in red). Paper copies of the map for this precinct are included on two sheets (the edges of the sheets are marked in green). They are now made available in such form [19]. In accordance with the adopted rule of division into precincts, the map of a given precinct was created on a fragment of a detailed map section. Often the adjacent detailed map sections on one triangulation sheet were combined into one sheet. The map section fragments on the sheet were numbered with Roman numerals. The frame that was often left on the map was the one closest to the area presented on the map. In the case of the map of the Lobzow precinct, a fragment of the map section "WC XL 12ag" was combined with a fragment of the map section "WC XL 12ah" and constitutes one, western sheet (with the markings I at the top and III at the bottom) (Fig. 2). Both above-mentioned map sections are located on the "WC XL" triangulation sheet. Similarly, one sheet (marked II and IV) is a combination of fragments of map sections "WC XXXIX 12dg" and "WC XXXIX 12dh".

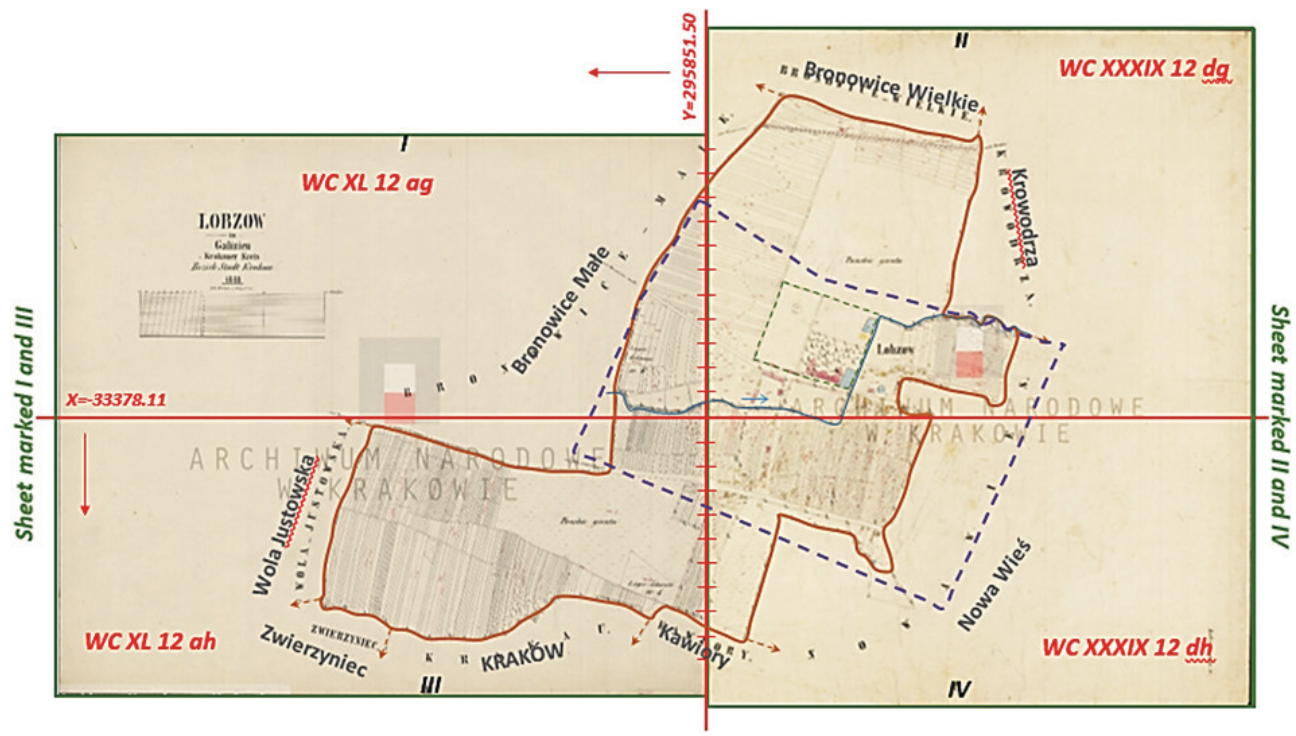

Fig. 2. Fragments of sheets of the cadastral map for the Lobzow precinct in Krakow Source: own elaboration based on [19] 
The scans of both sheets of the cadastral map shown in Figure 2 were made readable. They were supplemented with the missing numbers of the detailed map sections. The existing frames and inch marks were accentuated, as well as the border of the Lobzow precinct; the names of the neighbouring precincts were enlarged. The plan was also supplemented with the directions of the $X$ and $Y$ axes of the cadastral system. The area covered by the plan of Lobzow is marked with a dashed line (purple). Thanks to this, it can be seen that the plan showed the most developed part of Lobzow. In addition to a part of the Lobzow precinct, the plan of Lobzow also includes the western part of the Nowa Wieś precinct, and on the western side - also a small part of the Bronowice Małe precinct (Fig. 2). It is in this part of the plan that its border coincides with the border between Lobzow and Bronowice Małe precincts on the longest section.

\section{Determining the Scale of the Plan of Lobzow}

To determine the scale of the plan, its 600 dpi raster scan was used, made available to the author by the Historical Museum of the City of Krakow. Due to the lack of information concerning the details of drawing the plan, such as reference area, map projection, etc., the only way to determine the scale of the plan is to compare the corresponding lengths on the plan with true lengths. This method was used in the examination of the Kołłąaj's Plan [6]. However, due to the relatively poor and significantly changed topography of Lobzow, it was decided that the plan's scale would be determined with the use of a cadastral map. The topography presented on the plan corresponds to that shown on the cadastral map, which makes it easier to find corresponding reference points on the plan and on the map. To identify such points, a fragment of the cadastral map was used (part of the combined map sections WC XXXIX dg and dh) that covers the area surrounding the Lobzow garden (Fig. 3a).

a)

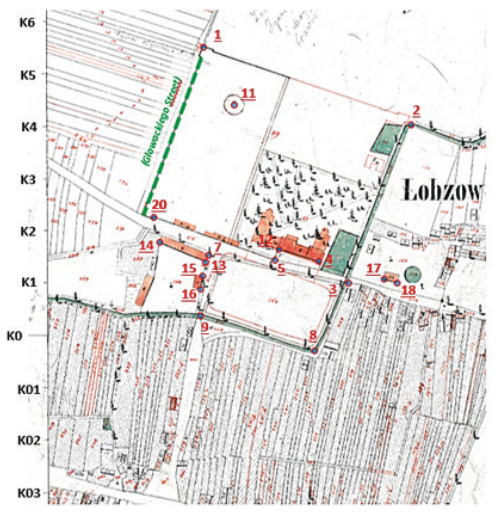

b)

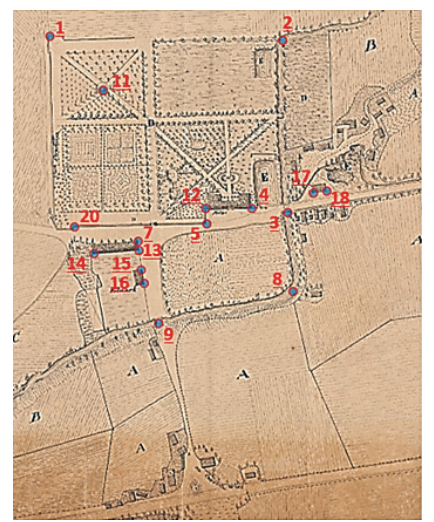

Fig. 3. Area of the palace and garden in Lobzow: a) fragments of the eastern sheet of the cadastral map of the Lobzow precinct; b) a fragment of the plan of Lobzow 
First, the scale of the raster of the map was calculated. For this purpose, 10 inch marks on the western, meridional frame of the sheet were used. Nine lengths between successive marks from $\mathrm{K} 6$ to $\mathrm{K} 03$ on the raster of the map were compared (Fig. 3a) with the nominal, field value of this distance (1):

$$
m_{R M}=\frac{z[\mathrm{~m}]}{D_{R M}}=\frac{1[\mathrm{~m}]}{213.93 \pm 2}
$$

where:

$m_{R M}$ - scale of the raster of the cadastral map,

$D_{R M}$ - an average distance between inch marks in the units of the map raster.

The slight inaccuracy of the scale calculated in this way (standard deviation \pm 2 ) results from inaccuracies in the drawing of the sheet, deformation of the paper it is drawn on, scanning inaccuracy and inaccuracy in the identification of the inch mark on the raster. The calculated scale characterises only the meridional direction, as there is no latitudinal frame on the sheet. It is worth noting, however, that this fragment of the plan of Lobzow is located close to the meridional frame of the map (Fig. 3a), but also close to the latitudinal frame (Fig. 2). Thus, it can be assumed that the value of the scale in both the latitudinal and the meridian direction may be similar.

Subsequently, the $m_{R M}$ scale was used to calculate the terrain coordinates of nineteen selected points on the map $(X, Y)_{M T}$ with the formula (2), based on their raster coordinates $(X, Y)_{M R}$ :

$$
(X, Y)_{M T}=m_{M R} \cdot(X, Y)_{M R}
$$

The points were the corners of buildings or fences, river bends or other characteristic landmarks (Fig. 3a). In this way, the location of the points in a certain local terrain system was obtained. These points were clearly identified also on the plan of Lobzow (Fig. 3b). The terrain coordinates of the points on the map $(X, Y)_{M T}$ were used to calculate the length of sections between the points $\left(d_{M T}\right)$.

The next step was to calculate the scale of the raster of the plan of Lobzow. It was necessary because the plan of Lobzow was made available only in the form of a raster. The value of the raster scale was obtained by comparing the length and width of the plan in raster units and nominal units of the paper sheet [2]. The average scale of the plan raster was $m_{P-P R}=1 \mathrm{~m} / 0.93587282 \pm 0.009$. The value of this scale is definitely less accurate. This is mainly due to uneven, damaged corners of the plan.

The measured distances between the points on the plan raster were then re-scaled according to the $m_{P-P R}$ value. In this way, the distances between points on the plan $\left(d_{P}\right)$ were obtained. Finally, the $m_{p}$ plan scale was calculated using the formula (3):

$$
m_{P}=\frac{d_{P}[\mathrm{~m}]}{d_{M T}[\mathrm{~m}]}
$$


The 42 longest sections between the selected points ( $2 / 3$ of all sections between the identified reference points) were chosen for calculations with the formula (3). These sections were between $286 \mathrm{~m}$ and $472 \mathrm{~m}$ long and had varying azimuths. The average value of the plan scale calculated using the formula (3) for the above-mentioned segments was 1:2900, with the standard deviation of the scale denominator amounting to \pm 88 . The calculated value of the plan scale roughly corresponds to the scale of the cadastral map (1:2880). The high value of the standard deviation results mainly from the inaccuracy of the raster scale $\left(m_{P-P R}\right)$ and the identification of points on the map raster and plan raster. It should be assumed that making the original plan of Lobzow available for research could contribute to determining a more precise value of the scale of this document.

\section{Establishing the Orientation of the Plan of Lobzow}

The nominal orientation of the plan of Lobzow is determined by the direction of the arrow described with the word "North" (Fig. 1). Its azimuth in the system of the plan raster is $32.63^{\circ}$. Taking into account the probable time of the plan's creation and the lack of information about the use of cartographic projection, it should be assumed that this is the direction of the magnetic north. It differs from true north by the value of the time-varying magnetic declination. On the other hand, on the cadastral map, after adopting (as a result of projection) the two-dimensional coordinate system $X Y$, the topographic north is determined. It differs from the true north by the convergence angle of the meridians. It depends on the type and parameters of cartographic projection. The azimuths of the sections between the points on the map were used to analyse the north direction marked on the plan of Lobzow. The comparison of the azimuths of the sections on the plan and on the map is aimed at assessing the correct orientation of the plan.

At the first stage, the difference of the azimuths of the sections on the plan raster and map raster was calculated. For this purpose, the above-mentioned 42 sections between selected and corresponding reference points on the map and plan were used. For each such section, the azimuth was measured on the map raster $\left(A_{M}\right)$ and the plan raster $\left(A_{P}\right)$. The mean difference of these azimuths was: $\Delta A_{M-P}=A_{M}-A_{P}=23.08^{\circ} \pm 2^{\circ}$. Therefore, in order for the topographic content of the map to coincide with the relevant topographic content of the map, the raster of the plan should be rotated by an angle of $-23.08^{\circ}$. After such a rotation, the azimuth of the north arrow on the plan raster will have the value of $9.55^{\circ}$. As a result of this rotation, the plan will have the orientation of a standard modern map, that is, an orientation in relation to the topographic north of the map.

At the second stage, it was necessary to take into account the convergence of the meridians for the map in the Lobzow region. Due to the uncertain type of projection used to compile the cadastral map [20], the value of this convergence was 
estimated in approximation. For this purpose, the only direction on the map that seems to have been preserved was used, i.e. the direction marked by the western fence of the Lobzow garden (marked with a green line in Figure 3a). This fence has been preserved to this day and, like almost 200 years ago, it constitutes the administrative border of Lobzow. The azimuth of this direction measured on the map raster is $20.42^{\circ}$. In turn, the geographical azimuth of this direction calculated from the ellipsoidal coordinates (GRS80 ellipsoid, PL-ETRF89 reference system) is $16.95^{\circ}$. Thus, the approximate convergence of the meridians for the cadastral map in this area of Lobzow is $\gamma_{M}=-3.47^{\circ}$. This means that the map frame along the $X$ axis of the cadastral system deviates to the west by the above value. It is worth noting that this value roughly corresponds to the meridian convergence calculated for the Soldner projection of the Bohnenberger ellipsoid ( $a=6376602 \mathrm{~m}, f=1 / 324$ ), used in the mid-19th century in this part of Europe. The value of this meridian convergence at the point in the Lobzow area $\left(\varphi=50.08^{\circ}, \lambda=19.91^{\circ}\right)$ in relation to the starting point of the cadastral system - Lviv, the Castle Hill $\left(\varphi=49.85^{\circ}, \lambda=24.04^{\circ}\right)-$ is $-3.40^{\circ}$. This confirms the relationship between the projection of the cadastral map and the Soldner projection [20].

After taking into account the convergence of the meridians for the plan of Lobzow, both the cadastral map and the plan of Lobzow would be oriented to true north. The azimuth of the north arrow from the plan of Lobzow, measured after such an operation, has the value $-13.02^{\circ}$. Such a value, amounting to a dozen or so degrees of deviation to the west, corresponds to the magnetic declination present in the Krakow region in the mid-19th century [21] ${ }^{4}$. The convergence of these values proves that the orientation of the plan of Lobzow, defined by the north arrow, indicates the direction of the magnetic north, probably established by the author of the plan with a compass.

Figure 4 shows the orientation of the cadastral map (blue) and the plan of Lobzow (sepia) with respect to the true north. The orientation of an additional arrow on the plan of Lobzow (purple) is also shown. Its direction deviates to the east of the true north by $11.86^{\circ}$.

The last stage of research on the plan of Lobzow was to place its topographic content against the background of the contemporary topography of this area (Fig. 5). The aim of this was to highlight the changes in land use that have occurred over the 200 years since the plan was created. Figure 5 shows generalised areas of diverse agricultural use, which dominated in the Lobzow area at that time.

The only area that has retained its former function is a small, north-eastern area of the palace garden, which now houses the gardening company "Ogród Łobzów".

4 In 2020, the magnetic declination in the Krakow region is positive (deviation to the east) and amounts to almost $6^{\circ}[22]$. 


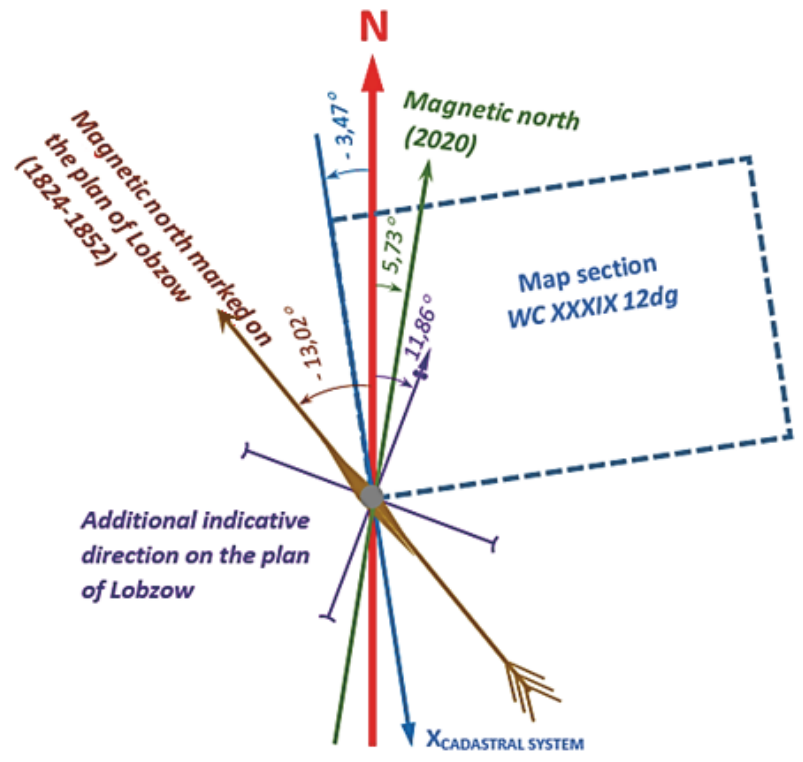

Fig. 4. Orientation of the plan of Lobzow and the cadastral map

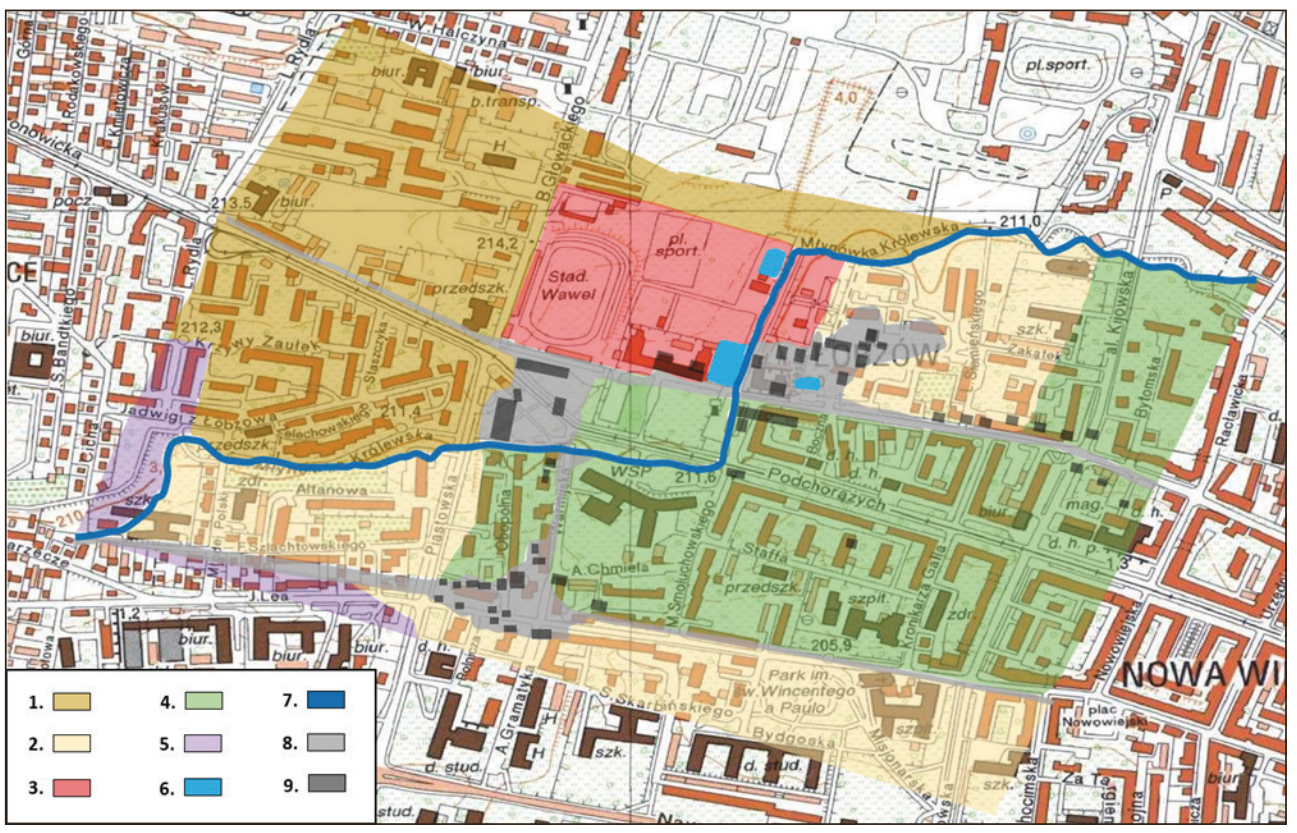

Fig. 5. Changes in the topography of Lobzow over the last 200 years:

1 - folwark land, 2 - peasant land, 3 - palace garden, 4 - vegetable gardens, 5 - pasture, 6 - fish ponds, 7 - river, 8 - roads and squares, 9 - buildings

Source: own elaboration based on [23] 


\section{Conclusions and Discussion}

The "Map of Lobzow with Its Environs", also known as "K. Gołuchowski's Plan", is one of the few cartographic documents presenting the 19th-century topography of the village of Lobzow near Krakow. This plan was most likely created in the years 1824-1852. This is evidenced by information on the property of the palace and the adjacent garden, as well as the condition of the topography of the area similar to that presented in other cartographic documents from that period. The plan of Lobzow is an example of those local cartographic documents that have few cartometric features. At the same time, it contains a lot of valuable information about the former topography and use of this area, almost completely changed today. It also included information on types of properties and elements of relief that are missing, for example, on the cadastral map. Hence, documents such as the plan of Lobzow may still be used, for example, in landscape change studies, provided that the basic features of the cartographic document, such as the scale and orientation, are established. This is all the more so because the plan of Lobzow has not been examined in this respect so far. The scales of this type of old cartographic documents devoid of information about the reference area and projection are most often determined in relation to the topographic details that have been preserved to this day. This procedure was used, for example, in examining of the scale of the 18th-century Kołłataj Plan [6]. However, in the case of the plan of Lobzow, this method is not possible because most of the topography of this area has been changed. Therefore, it was decided to compare the plan with the cadastral map on which the presented topography corresponds in part to that from the plan of Lobzow. The average scale factor of 1:2900 determined as a result of the calculations suggests that the plan of Lobzow could be a hand-drawn copy of this map or be based on measurement sketches that were the basis for drawing the map. The large standard deviation of the scale denominator $( \pm 88)$ indicates heterogeneity of the scale in the central part of the plan. The edge fragments of the plan can be characterised by even greater variability of the scale, as can be seen in the example of the course of the Młynówka Królewska River (Fig. 5). The lack of other references in the topography makes it impossible to assess the scale of the plan in its edge parts.

The orientation of the plan marked with the north arrow refers to the magnetic north as it was in the mid-19th century in this region of Poland. It was established based on one of the unchanged elements of the plan drawing that defines direction, i.e. the western border of the Lobzow garden area (Figs. 1, 3a). The correspondence of this direction with the true north indicated by the $X$ axis of the cadastral map system, after taking into account the meridian convergence, is at the level of approximately $1^{\circ}$. For the plan of Lobzow to be oriented in relation to the current direction of magnetic north, it would have to be rotated clockwise by almost $19^{\circ}$. 
The meaning of the additional direction marked on the plan near the north arrow has not been established (Figs. 1, 4). It was noticed that this arrow was perpendiculars to the rectilinear direction of the road at the southern end of the plan (today's Juliusza Lea Street, Fig. 1). The direction of this road together with the perpendicular direction of the arrow could constitute a local rectangular coordinate system for determining the location of objects on the plan.

The placement of the topography of the plan of Lobzow against the background of the contemporary topography of this part of Krakow indicates that there are some communication routes whose course has remained almost unchanged to this day (Fig. 5). This applies to parts of the following streets: Bronowicka, Głowackiego, Kazimierza Wielkiego, Warmijska and Lea. It is also worth noting that both wells marked on the plan of Lobzow (Fig. 1) are located on the site of the currently functioning artesian well ("Zdrój Nadzieja") at Podchorążych Street. The plan of Lobzow placed on the contemporary topographic map shows a definite change in the state of land use in the area of Lobzow. Currently, almost the entire area covered by the plan is an area of dense urban development, and the area of Lobzow lost the status of a village near Krakow as early as in 1910, becoming a district of Krakow. A relic of the state of land development of this area from the mid-19th century is the course of some communication routes, the western fence of the palace garden and the activity of the company "Ogród Łobzów" established next to the palace garden and referring to the almost 500-year-old gardening tradition of the village of Lobzow.

\section{References}

[1] Rączka J.W.: Królewska rezydencja pałacowo-ogrodowa na Łobzowie. Stan badań i zachowane źródła archiwalne (1367-1586). Teka Komisji Urbanistyki i Architektury, t. 16, 1982, pp. 17-30.

[2] MHK: Plan części Łobzowa z pałacem i ogrodem. http://ct.mhk.pl/wps/portal/ $\mathrm{mhmk} / \mathrm{main} / \mathrm{strona}-$ artefaktu$/$ ?artefactId=\{8BD06E58-5091-429E-8E1A-5418 43F66472\} [access: 10.02.2021].

[3] Szady B.: Dawna mapa jako źródto w badaniach geograficzno-historycznych w Polsce. Kwartalnik Historii i Kultury Materialnej, t. 66(2), 2018, pp. 129-141.

[4] Konias A.: Metody oceny dokładności dawnych map. [in:] Gurba S. (red.), Teoretyczne i metodyczne problemy wspótczesnej kartografii: XIII Ogólnopolska Konferencja Kartograficzna, Lublin 11-12 IX 1984, Materiały Ogólnopolskich Konferencji Kartograficznych, t. 10, Lublin 1984, pp. 64-76.

[5] Konias A.: Kartografia topograficzna Ślaska Cieszyńskiego i zaboru austriackiego od II połowy XVIII wieku do poczatku XX wieku. Wydawnictwo Uniwersytetu Śląskiego, Katowice 2000. 
[6] Odlanicki-Poczobutt M., Traczewska-Białek Z.: Plan Kołłatajowski miasta Krakowa z roku 1785. Zeszyty Naukowe Akademii Górniczo-Hutniczej im. Stanisława Staszica. Geodezja, z. 110, AGH, Kraków 1990.

[7] Krzywicka-Blum E.: Nowa metoda analizy i prezentacji zmienności skali dawnych map dużych obszarów. Polski Przegląd Kartograficzny, t. 26, nr 2, 1994, pp. 75-84.

[8] Knowles A.K.: Emerging Trends in Historical GIS. Historical Geography, vol. 33, 2005, pp. 7-13.

[9] Podobnikar T.: Georeferencing and quality assessment of Josephine Survey maps for the mountainous region in the Triglav National Park. Acta Geodaetica et Geophysica Hungarica, vol. 44, iss. 1, 2009, pp. 49-66. https://doi.org/10.1556/ AGeod.44.2009.1.6.

[10] Affek A.: Kalibracja map historycznych z zastosowaniem GIS. [in:] Plit J., Nita J., Źródła kartograficzne w badaniach krajobrazu kulturowego. Prace Komisji Krajobrazu Kulturowego, nr 16, Komisja Krajobrazu Kulturowego Polskiego Towarzystwa Geograficznego, Sosnowiec 2012, pp. 48-62.

[11] Timár G., Biszak S.: Digitizing and georeferencing of the historical cadastral maps (1856-60) of Hungary. [in:] 5th International Workshop on Digital Approaches in Cartographic Heritage. Vienna, Austria, 22-24 February 2010, pp. 559-564.

[12] Herrault P.A., Sheeren D., Fauvel M., Monteil C., Paegelow M.: A comparative study of geometric transformation models for the historical "map of france" registration. Geographia Technica, no. 1, 2013, pp. 34-46.

[13] Ostafin K., Kaim D., Troll M., Maciejowski W.: The authorship of the Second Military Survey of Galicia and Austrian Silesia at the scale 1:28800 and the consistency of sheet content based on selected examples. Polish Cartographical Review, vol. 52(4), 2020, pp. 141-151. https://doi.org/10.2478/pcr-2020-0012.

[14] Murzewski W.: Rozwój triangulacji na południu Polski. Wiadomości Służby Geograficznej, R. 10, 1936, pp. 208-238.

[15] Fedorkowski W.: Ewidencja gruntów. Państwowe Przedsiębiorstwo Wydawnictw Kartograficznych, Warszawa 1974.

[16] Banasik P.: Wyznaczenie położenia kopca Esterki na podstawie dawnych map z obszaru Krakowa. Geodeta, nr 10, 2009, pp. 52-58.

[17] Rączka J.W.: Królewska rezydencja pałacowo-ogrodowa na Łobzowie. Stan badań i zachowane źródła archiwalne (1585-1655). Teka Komisji Urbanistyki i Architektury, t. 17, 1983, pp. 25-40.

[18] Rączka J.W.: Królewska rezydencja pałacowo-ogrodowa na Łobzowie. Stan badań i zachowane źródła archiwalne (1655-1920). Teka Komisji Urbanistyki i Architektury, t. 18, 1984, pp. 47-58.

[19] Szukaj w Archiwach: https://szukajwarchiwach.pl/29/280/0/9.1/1228/str/1/1/ 15/Pbz5-cHU5JC5H0rQrJHRig/\#tabSkany [access: 10.02.2021].

[20] Biernacki F.: W sprawie wspótrzędnych katastralnych w Małopolsce. Wiadomości Służby Geograficznej, R. 8, 1934, pp. 547-553. 
[21] Jackson A., Jonkers A.R.T, Walker M.R.: Four centuries of geomagnetic secular variation from historical records. Philosophical Transactions of the Royal Society A, vol. 358, iss. 1768, 2000, pp. 957-990. https://doi.org/10.1098/ rsta.2000.0569.

[22] Magnetic-Declination: https://www.magnetic-declination.com/ [access: 10.02.2021].

[23] Geoportal: https://mapy.geoportal.gov.pl/imap/Imgp_2.html?gpmap=gp0 [access: 10.02.2021]. 